\title{
Öğretmenlerin Eğitim İnançları ile Meslekî Değerleri Arasındaki İlişki ${ }^{1}$
}

\author{
Dr. Nihal TUNCA* \\ Dumlupınar Üniversitesi, Eğitim Fakültesi, Eğitim Bilimleri Bölümü, Evliya Çelebi Kampüsü, \\ Kütahya / Türkiye
}

\section{Dr. Senar ALKIN ŞAHIN}

Dumlupınar Üniversitesi, Eğitim Fakültesi, Eğitim Bilimleri Bölümü, Evliya Çelebi Kampüsü, Kütahya / Türkiye

\section{Doç. Dr. Aytunga OĞUZ}

Dumlupınar Üniversitesi, Eğitim Fakültesi, Eğitim Bilimleri Bölümü, Evliya Çelebi Kampüsü, Kütahya / Türkiye

\section{$\ddot{O} z$}

$\mathrm{Bu}$ araştırmada, öğretmenlerin, eğitim inançlarını ve meslekî değerleri benimseme düzeylerinin; eğitim inançlarının ve meslekî değerlerinin bazı değişkenlere göre farklılaşıp farklılaşmadığının, eğitim inançları ile meslekî değerleri arasında anlamlı

\footnotetext{
$1 \mathrm{Bu}$ çalışma, İstanbul Üniversitesi'nde düzenlenen 1. Avrasya Eğitim Araștırmaları Kongresi'nde (İstanbul, 24-26 Nisan 2014) sunulan bildirinin geliştirilmiş hâlidir. 
bir ilişki olup olmadığının belirlenmesi amaçlanmıştır. Araştırma ilişkisel tarama modelindedir. Araştırmanın örneklemini, 2013-2014 Eğitim-Öğretim Yılı Güz Dönemi'nde Afyon ilinde fen ve teknoloji, matematik, sınıf, sosyal bilgiler ve Türkçe branşlarında görev yapan toplam 253 öğretmen oluşturmaktadır. Araştırma verilerinin toplanmasında Yılmaz, Altınkurt ve Çokluk (2011) tarafından geliştirilen "Eğitim İnançları Ölçeği” (EİÖ) ve Tunca (2012) tarafından geliştirilen “Öğretmen Meslekî Değerler Ölçeği (ÖMDÖ)” kullanılmıştır. Verilerin çözümlenmesinde, betimsel istatistikler, ANOVA, Kruskall Wallis H testi ve Pearson Momentler Çarpımı Korelasyon Katsayısı kullanılmıştır. Araştırmadan elde edilen bulgular doğrultusunda, eğitim inançları açısından öğretmenlerin en yüksek katılım gösterdiği boyutun varoluşçuluk, en az katılım gösterdiği boyutun ise esâsîcîlik olduğu; eğitim inançlarının öğrenim seviyesine göre yalnızca dâimîcilik boyutunda; görev yaptıkları okulun sosyo-ekonomik seviyesine göre yeniden kurmacılık ve dâimîcilik boyutlarında farklılaştığı, branşa göre farklılaşmadığı sonucuna ulaşılmıştır. Meslekî değerleri açısından ise öğretmenlerin kendilerini yüksek düzeyde algıladıkları; önlisans, lisans ya da lisansüstü öğrenim gören öğretmenlerin benzer seviyede meslekî değerlere sahip olduğu; görev yaptıkları okulun sosyo-ekonomik seviyesine göre "Kişisel ve Toplumsal Sorumluluk ve İşbirliğine Açık Olma” boyutları ile ÖMDÖ’den aldıkları toplam puanlarında farklılaştığı sonucuna ulaşılmıştır. Ayrıca araştırmada öğretmenlerin eğitim inançları ile meslekî değerleri arasında orta düzeyde pozitif ve anlamlı ilişkiler olduğu belirlenmiştir.

Anahtar Kelimeler: Eğitim inanc1; Eğitim felsefesi; Meslekî değer; Öğretmen eğitimi.

\title{
The Relationship Between
}

\section{Teachers' Educational Beliefs and Professional Values}

\begin{abstract}
In the current study, the purpose is to determine the relationship between teachers' educational beliefs and professional values and to investigate whether their educational beliefs and professional values vary significantly depending on some variables. The study was designed in the relational survey model. The sampling of the present study consists of 253 science and technology, mathematics, classroom, social studies and Turkish teachers working at schools of the city of Afyon in 2013-2014 school year. In the collection of the data, "Educational Be-
\end{abstract}


liefs Scale" (EBS) developed by Yılmaz, Altınkurt and Çokluk (2011) and "Teaching Professional Values Scale" (TPVS) developed by Tunca (2012) were employed. In the analysis of the data, descriptive statistics, Pearson Product-Moment Correlation Coefficient, ANOVA and Kruskall Wallis $\mathrm{H}$ test were run. In line with the findings of the present study, it can be argued that in relation to educational beliefs, the teachers displayed the highest participation in the dimension of existentialism and the dimension in which they demonstrated the lowest participation was found to be essentialism; educational beliefs only varied significantly in the dimension of perennialism depending on their education level; depending on the socio-economic status of the school, educational beliefs only varied significantly in the dimensions of re-constructionism and perennialism and did not vary depending on the branch of the teachers. In terms of professional values, the teachers think of themselves highly positively; the teachers graduating from two-year degree programs, undergraduate programs and graduate programs possess similar professional values and the scores taken from the dimensions of Personal and Societal Responsibility and Openness to Co-operation and the whole TPVS varied significantly depending on the socio-economic status of the school. Moreover, a positive and moderately significant correlation was found between the teachers' educational beliefs and professional values.

Keywords: Educational belief; Educational philosophy; Professional value; Teacher education.

\section{Extended Summary}

\section{Purpose}

In the present study, the purpose is to determine the relationship between teachers' educational beliefs and professional values and to investigate whether their educational beliefs and professional values vary significantly depending on some variables.

\section{Methods}

The study conducted to determine the correlation between the teachers' educational beliefs and their professional values was designed 
in the relational survey model. The relational survey model aims to determine the existence and level of the covariance between two or more variables (Karasar, 2005).

\section{Results}

When the educational beliefs of the teachers were investigated in the current study, it was found that they demonstrated the highest participation in the dimension of existentialism and the lowest participation in the dimension of essentialism. When the teachers' possession of the professional values was examined, it was found that they possess these values to a great extent. When the teachers' educational beliefs were explored in relation to their education level, it was found that there is a significant difference in relation to the dimension of perennialism favoring the graduates of two-year degree programs. When the teachers' professional values were investigated in relation to their education level, it was found that they possess professional values at similar levels. When the teachers' educational beliefs were examined in relation to the socio-economic status of their school, it was found that the teachers working at schools of higher socio-economic status adopted the re-constructionism and perennialism educational philosophies more than the teachers working at schools of low socio-economic status and middle socio-economic status. When the teachers' professional values were investigated depending on the socio-economic status of the school, it was concluded that the teachers working at schools of high socio-economic status displayed a greater level of the value of respecting differences than the teachers working at schools of lower so- 
cio-economic status. When the teachers' educational beliefs were examined in relation to their subject area, no significant difference was found. When the teachers' professional values were explored in relation to their subject area, the scores taken from the dimensions of Personal and Societal Responsibility and Openness to Co-operation and the whole TPVS were found to vary significantly. In the current study, medium level and positive significant correlation was found between the teachers' professional values and educational beliefs.

\section{Discussion and Conclusion}

In light of the findings of the present study, it can be claimed that the teachers have adopted contemporary educational philosophies. The qualities and application principles of education programs are determined on the basis of the adopted education philosophy. Given that elementary and secondary school programs are based on contemporary educational philosophies such as progressivism and re-constructionism, it is natural to expect teachers that are the implementers of the program to have adopted contemporary education philosophies. Moreover, though teachers are not educated based on some certain education philosophies during their pre-service education, they develop some opinions and beliefs as a result of their education (Austin and Reinhardt, 1999; Kagan, 1992; Pajares, 1992). In line with this view, the findings of the current study may indicate that the pre-service teacher training taken by teachers develops and nurtures their perception of the philosophies of contemporary education. When the research in literature on educational beliefs adopted by teachers/pre-service teachers is 
examined, it has been seen that in a similar vein with the current study, many studies concluded that teachers/pre-service teachers have adopted contemporary philosophies of education (Livingston, McClain and DeSpain, 1995; Alkın-Şahin, Tunca and Ulubey, 2013; Erbaş, 2013; Tunca, Alkın-Şahin and Oğuz, 2014; Kanatlı and Schreglman, 2014). When the teachers' state of possessing professional values was examined, it was found that they have a quite positive perception of themselves. Yet, the sub-dimension in which the teachers consider themselves to be quite inadequate is "Their being against violence". With the renewal of the elementary school program in 2005, the philosophy on which the program was grounded changed and accordingly perceptions of teacher and student roles also changed. The student was put into the center of the program and their needs and attitudes were given greater priority. Moreover, in order to ensure the safety of students and achieve the desired success from the education system, a circular was issued by the Ministry of National Education on 14.03.2006 stipulating that "Aggressive behaviors, bullying and violence between teacher and student, student and student, school and family, family and student will not be tolerated." Considering both the renewal of the program and the attitude of the Ministry of National Education towards aggression, it was expected that the teachers would adopt the value of "Being Against Violence" to a greater extent. However, other research in the literature also supports this finding (Hatunoğlu and Hatunoğlu, 2005; Gözütok, 2008; Tunca, 2012). The current study revealed that the teachers' educational beliefs only significantly varied in the dimension of perennialism depending on edu- 
cation level and this difference favors the graduates of two-year degree programs. This may be because the education they gave was based on perennialism and essentialism until the program renewal in 2005 and their adopted philosophies of education were resistant to change (Kagan, 1992; Pajares, 1992). In the present study, it was found that the teachers working at schools of higher socio-economic status adopted the re-constructionism and perennialism educational philosophies more than the teachers working at schools of low socio-economic status and middle socio-economic status. Schools of higher socio-economic status can provide students with better physical infrastructure and socio-cultural conditions. Thus, the teachers working in such schools may have exhibited more commitment to re-constructionism theory arguing that the purpose of education is to re-construct and to foster the society and schools are important means of societal change. The reason for their adopting perennialism may be because the exam system of the country is competitive and focused on the testing of memorization-based cognitive skills and the achievement of schools is determined on the basis of the outcomes of this exam system. The reason for classroom teachers' adopting the value of Personal and Societal Responsibility more than mathematics and social studies teachers may be because the classroom teacher is viewed as a sole role model by students; hence, they should assume greater responsibility in the training of good citizens. Medium level and positive correlations were found between the teachers' professional values and progressivism, existentialism, re-constructionism and perennialism education philosophies. Given that an education system constructed on the basis of the educa- 
tional philosophies of progressivism and re-constructionism aims to ensure co-operation among individuals and rearrange the society by fostering democratic and social living patterns (Sönmez, 1996), stronger correlation was expected between the variables. When the correlations between the dimensions of educational beliefs and professional values scales were investigated, it was found that the highest correlation is between Existentialistic education and the value of Showing Respect to Differences. It is an expected result to find a high correlation between existentialistic education supporting the recognition of the personal characteristics of each student and liberalization of students by not imposing a single fact and by being unbiased during classroom discussions (Y1lmaz, Altınkurt and Çokluk, 2011) and the value of showing respect to differences.

\section{Giriş}

Eğitimin niteliğine, öğretmen, öğrenci, program, ders kitab1, yardımcı kaynaklar, araç-gereçler vb. olmak üzere pek çok değişken tesir etmektedir. Programların uygulayıcıları olmaları; öğrencilerin bilişsel, duygusal, sosyal gelişimi üzerinde etkili olmaları; “öğrenmeyi sağlama, sınıf yönetimi, aile üyeliği, değerlendirme, güven verme, meslekî yeterlik, toplum lideri olma (Havighursl ve Ncu-Gartcn, 1967, akt; Sünbül, 1996)" gibi rol ve sorumluluklara sahip olmaları nedenleriyle öğretmenler, eğitimin niteliğini etkileyen diğer değişkenlere göre hayatî öneme sahiptir. Öğretmen, meslekî ve kişisel yeterliliği, sahip olduğu eğitim inançları ve değerleri açısından programın öngördüklerini gerçekleştirecek bir niteliğe sahip değilse, en mükemmel program 
bile öğretmenin elinde işlevselliğini kaybedebilir (Tunca, 2012). Öğretmenlerin programları işlevsel biçimde uygulamalarını, rol ve sorumluluklarını yerine getirmelerini ve öğrenmeyi ve düşünmeyi geliştiren sınıf içi davranışlar göstermelerini etkileyen önemli değişkenlerden biri sahip oldukları eğitim inançlarıdır.

Eğitim inançları, bireyin öğrenme ve öğretmeye ilişkin felsefesi, kanıları, ilkeleri ve görüssleri olarak tanımlanmaktadır (Haney, Lumpe ve Czerniak, 2003). Porter ve Freeman (1986) eğitim inançlarını; öğretmenlerin, öğrenciler ve öğrenme süreci, program, öğretmenlik meslek bilgisi, okulun toplumdaki yeri ile ilgili inançlarını içeren öğretim yönelimleri olarak tanımlamıştır (akt; Pajares, 1992). Eğitim inançları, öğretmenlerin algılarını, yargılarını, sınıf içi davranışlarını, öğretim uygulamalarını ve öğrencilerin nasıl öğrendiklerini etkilemektedir (Beijaard, 1998, akt; Hermans, Tondeur, Valcke ve Van Braak; Fang, 1996; Kagan, 1992; Karakuş, 2006; Pajares, 1992). Bu nedenle öğretmenlerin inanç yapılarını belirlemenin hizmet öncesi öğretmen eğitimi programlarının ve öğretim uygulamalarının iyileştirilmesinde önemli olduğu vurgulanmaktadır (Pajares, 1992).

Alan-yazına göre eğitim inançlarının belirleyicisi, "eğitim felsefesi"dir (Pajares, 1992; Seshadri, 2008; Yılmaz, Altınkurt ve Çokluk, 2011). Eğitimde amaçların belirlenmesine, içeriğin düzenlenmesine, öğrenme öğretme sürecinde kullanılacak strateji, yöntem ve tekniklerin seçimine, öğrenci ve öğretmen rolleri ile sınama durumlarının belirlenmesine kısaca öğretim programlarının şekillendirilmesine yön veren eğitim felsefesi (Erden, 1998), eğitim politikalarına ve uygulamalarına 
yön veren bir disiplin ya da sistemli fikir ve kavramlar bütünü olarak tanımlanabilir (Büyükdüvenci, 1991).

Eğitim inançlarını belirleyen başlıca eğitim felsefeleri "Dâimîcilik, Esâsîcilik, İlerlemecilik, Yeniden Kurmacılık ve Varoluşçuluk" olarak ele alınabilir. Bu akımlardan geleneksel olarak kabul edilen “Dâimîcilik" ve "Esâsîcilik", "Realizm” ve "İdealizm” felsefelerine dayanmaktadır. Dâimîciliğe göre eğitimin amacı, aklını tutarlı kullanan, ahlâkî değerlere, evrensel ilkelere, gelenek ve göreneklere sahip bireyler yetiştirmektir. Esâsîciliğe göre ise eğitimin amacı, topluma uyumu sağlayan, başat kültürel değerleri kazanmış, bilgili ve becerili bireyler yetiştirmektir. Çağdaş eğitim felsefeleri olarak kabul edilen "İlerlemecilik" ve "Yeniden Kurmacılığın" dayandığg felsefe, "Pragmatizm"dir. İlerlemeciliğe göre eğitimin amacı toplumda demokrasiyi sağlayacak bireyler yetiştirmektir. İlerlemeciliğin devamı olarak görülen "Yeniden Kurmacılık" ise eğitim ile toplumu yeniden düzenlemeyi ve şekillendirmeyi amaçlar. Varoluşçuluğa göre ise eğitimin amacı, bireyin kendi kendisini yaratmasını sağlamak, bireyi sınır durumuna getirmek, özgür eylemde bulunmasına ortam sağlamak ve seçtiklerinden sorumlu bireyler yetiştirmektir (Sönmez, 2005).

Öğretmenlerin rol, görev ve sorumluluklarını yerine getirirken ideal olan davranışları yansıtmaları için sahip olmaları gereken diğer bir değişken ise meslekî değerlerdir. Meslekî değerler, bir mesleğin gerektirdiği ideal olan davranışların gösterilmesine ve yasaklanmış davranış örüntülerinin ya da onaylanmayan davranışların engellenmesine katkı sağlayan inançlar, ölçütler ya da standartlar olarak tanım- 
lanmaktadır. Öğretmenlik mesleği açısından düşünüldüğünde ise meslekî değerler, öğretmenlerin, öğretimi plânlama, düzenleme, uygulama; öğrencilerin öğrenmelerini sağlama ve sürdürme; sınıf içi disiplini sağlama; kendini geliştirme gibi meslekî görevlerini ve sorumluluklarını yerine getirirken düşüncelerine, duygularına ve davranışlarına rehberlik eden ölçütler ya da standartlar olarak tanımlanabilir. $\mathrm{Bu}$ değerler, ideal öğretmen davranışlarının belirlenmesinde, öğretmenlerin niyetlerinin ve davranışlarının kabul edilebilir ya da kabul edilemez; değerli ya da değersiz olarak yargılanmasında rehber ilkeler olarak da dikkate alınabilir (Tunca, 2012). Tunca (2012) öğretmenlik mesleğinin meslekî değerlerini belirlediği çalışmasında, öğretmenlerin öğretmenlik mesleğini yürütürken sahip olmaları beklenen önemli meslekî değerlerinin "Farkl1lıklara Saygı Duyma, Kişisel ve Toplumsal Sorumluluk Alma, İşbirliğine Açık Olma ve Şiddete Karşı Olma” olduğunu belirtmektedir.

$\mathrm{Bu}$ çerçevede, öğretmenlerin mesleklerini yürütürken gösterdikleri davranışların, üstlendikleri rol ve sorumlulukların; öğretimi planlama, uygulama, değerlendirme ve sınıf yönetimi gibi görevlerinin; benimsedikleri eğitim inançlarına ve meslekî değerlere göre şekillendiği söylenebilir. Buna bağlı olarak her iki değişken arasında kuramsal açıdan güçlü bir ilişki olduğu dikkat çekmektedir. Ancak alan-yazın incelendiğinde, öğretmenlerin duyuşsal özellikleriyle ilgili bu iki değişken arasındaki ilişkiyi inceleyen bir çalışmaya rastlanmamıştır. $\mathrm{Bu}$ ihtiyaçtan hareketle, bu araştırmada öğretmenlerin eğitim inançları ile meslekî değerleri arasındaki ilişkinin belirlenmesi amaçlanmıştır. 
Araştırmada yanıt aranan sorular şunlardır:

1. Öğretmenlerin eğitim inançlarını benimseme seviyeleri nedir?

2. Öğretmenlerin meslekî değerlere sahip olma seviyeleri nedir?

3. Öğretmenlerin eğitim inançları ve meslekî değerleri “öğrenim seviyesi, görev yapılan okulun sosyo-ekonomik durumu ve branş" değişkenlerine göre anlamlı olarak farklılaşmakta mıdır?

4. Öğretmenlerin eğitim inançları ile meslekî değerleri arasında anlamlı bir ilişki var mıdır?

\section{Yöntem}

Öğretmenlerin eğitim inançları ile meslekî değerleri arasındaki ilişkinin belirlenmesi amacıyla yapılan bu çalışma ilişkisel tarama modelindedir. İlişkisel tarama modelinde, iki ya da daha çok değişken arasında birlikte değişimin varlığg ve derecesi belirlenmeye çalışılmaktadır (Karasar, 2005). Bu araştırmada da öğretmenlerin eğitim inançları ile meslekî değerleri var olan hâliyle ortaya konulmaya ve bu iki değişken arasında birlikte değişimin olup olmadığı belirlenmeye çalışılmıştır.

\section{Evren ve Örneklem}

Araştırmanın evrenini, 2013-2014 Eğitim-Öğretim Yılı Güz Dönemi'nde Afyon ilinde fen ve teknoloji, matematik, sınıf, sosyal bilgiler ve Türkçe branşlarında görev yapan toplam 745 öğretmen oluşturmaktadır. Örneklem, oransız küme örneklemesi tekniği ile belirlenmiştir. Örneklem büyüklüğü \%95 güven düzeyi için 253 olarak hesaplanmıştır. Ölçeklerin doldurulmasında ve geri dönüşünde eksikliklerin olabileceği dikkate alınarak ölçme aracı 300 öğretmene uygu- 
lanmış, eksik ya da özensiz doldurulan veriler ayıklandıktan sonra analizler 253 kişi üzerinden yapılmıştır. Buna göre araştırmanın örneklemi, 253 ilkokul ve ortaokul öğretmeninden oluşmaktadır. Kat1lımciların \%51.4'ü kadın (N=130), \%48.6's1 erkektir (N=123). Kat1lımcıların \%33.2'si sınıf öğretmeni $(\mathrm{N}=84)$, \%18.6'sı matematik öğretmeni ( $\mathrm{N}=47)$ ve \%18.2'si Türkçe öğretmeni $(\mathrm{N}=46), \% 17.8$ 'i sosyal bilgiler öğretmeni $(\mathrm{N}=45), \% 12.3$ 'ü fen bilgisi öğretmenidir $(\mathrm{N}=31)$. Katılımcıların \%78.7'si lisans (N=199), \%13.47'si (N=34) lisansüstü, \%7.9'ü önlisans ( $N=20)$ öğrenimini tamamlamış olup \% 74,3'ü eğitim fakültesinden $(\mathrm{N}=188), \% 25.7$ 'si ise diğer fakültelerden $(\mathrm{N}=65)$ mezundur. Kat1lımcıların \% 24.1'i alt sosyo-ekonomik seviyedeki okulda $(\mathrm{N}=61)$, \%66's1 orta sosyo-ekonomik seviyedeki okulda $(\mathrm{N}=167)$, \%9.9'u ise üst sosyo-ekonomik seviyedeki okulda $(\mathrm{N}=25)$ görev yapmaktadır.

\section{Veri Toplama Araçları}

Araştırma verilerinin toplanmasında Yılmaz, Altınkurt ve Çokluk (2011) tarafından geliştirilen "Eğitim İnançları Ölçeği (EİÖ)" ve Tunca (2012) tarafından geliştirilen “Öğretmen Meslekî Değerler Ölçeği (ÖMDÖ)" kullanılmıştır. EİÖ, öğretmenlerin eğitim inançlarını belirlemeye dönük; "İlerlemecilik", "Varoluşçu Eğitim”, "Yeniden Kurmacılık", "Dâimîcilik" ve "Esâsîcilik" olmak üzere 5 alt ölçekten oluşmaktadır. Ölçekte likert tipi toplam 40 madde bulunmaktadır. Yanıt ölçeği, "1-Kesinlikle Katılmıyorum” ve "5-Kesinlikle Kat1liyorum” aralığında puanlanmaktadır. Ölçeğin ters puanlanan maddesi yoktur. Ölçekten toplam puan elde edilmemekte, katılımcıların her bir eğitim 
felsefesini ne kadar benimsedikleri belirlenmektedir. Bir alt ölçekten alınan yüksek puan, katılımcıların o alt ölçekteki eğitim felsefesine inandığını ve benimsediğini, düşük puan ise söz konusu felsefeye olan inançlarının az olduğunu belirtmektedir. Açımlayıcı faktör analizi sonucu ölçeğin faktör yük değerleri; "İlerlemecilik" alt boyutunda 0.50-0.73, "Varoluşçu Eğitim"de 0.58-0.74, "Yeniden Kurmacılık" boyutunda 0.52-0.68, "Dâimîcilik" boyutunda 0.42-0.61 ve "Esâsîcilik" boyutunda 0.61-0.73 arasındadır. Doğrulayıcı faktör analizi ile ölçek için oluşturulan modele uygun ki-kare $\left(\mathrm{X}^{2}\right)$ değeri istatistikî anlamlılık düzeyleri $\left(\mathrm{X}^{2} / \mathrm{sd}=2.23\right)$ hesaplanmıştır. Ayrıca modele ilişkin diğer uyum indeksleri de $(\mathrm{GFI}=0.85, \mathrm{AGFI}=0.83, \mathrm{RMSR} \leq 0.05$, RMSEA $\leq 0.05, R M R$ ve $S R M R \leq 0.08, C F I \geq 0.95$, NFI ve NNFI $\geq 0.95$, PGFI=0.75) önerilen modelin uygun olduğunu göstermiştir. Ölçeğin Cronbach's Alfa katsayıları alt ölçeklerde 0.70-0.91 arasında değişmektedir (Yılmaz, Altınkurt ve Çokluk, 2011). Araştırmada ölçeğin güvenirliği yeniden test edilmiş ve Cronbach's Alfa katsayılarının alt ölçeklerde 0.64-0.82 arasında olduğu belirlenmiştir.

ÖMDÖ ise 24 maddeden ve "Farkl1lıklara Sayg1 Duyma", "Kişisel ve Toplumsal Sorumluluk", "Şiddete Karşı Olma” ve "İ̧̧birliğine Açık Olma" adlarını taşıyan 4 alt boyuttan oluşmaktadır. Ölçeğin "Şiddete Karşı Olma” boyutunun bütün maddeleri ters puanlanmaktadır. Ölçekteki maddeler "1-Beni hiç yansıtmıyor" ve "5-Beni çok yansitıyor" aralığında puanlanmaktadır. Ölçeğin tamamından toplam puan alınabilmektedir. Ölçekten alınabilecek puanlar 24 ile 120 arasında değişmektedir. Ölçekten alınan puanların yükselmesi, öğretmenlerin 
meslekî değerlere sahip olma seviyesinin yükseldiğine işaret etmektedir. Ölçekte yer alan dört boyut, toplam varyansın \%46.57'sini açıklamaktadır. Ölçeğin açımlayıcı faktör analizi sonucu elde edilen dört faktör altında toplanan 24 maddelik yapısına, doğrulayıcı faktör analizi uygulanmıştır. Doğrulayıcı faktör analizi ile ölçek için oluşturulan modele uygun ki-kare $\left(\mathrm{X}^{2}\right)$ değeri istatistikî anlamlılık düzeyleri $\left(\mathrm{X}^{2} / \mathrm{sd}=2.29\right)$ hesaplanmıştır. Ayrıca modele ilişkin diğer uyum indeksleri de $(\mathrm{GFI}=0.88$, AGFI=0.86, RMSEA=0.06, SRMR, CFI, NFI ve NNFI=0.92) önerilen modelin uygun olduğunu göstermiştir. ÖMDÖ’nün güvenirliği için hesaplanan Cronbach's Alfa katsayısı alt boyutlar için 0.70-0.78 aralığında değişmektedir. Ölçeğin tamamı için Cronbach's Alfa katsayısı ise 0.82 olarak hesaplanmıştır (Tunca, 2012). Ölçeğin alt boyutlarının güvenirliği bu araştırmada yeniden test edilmiş ve 0.54-0.76 arasında olduğu görülmüştür. Ölçeğin tamamının Cronbach's Alfa katsayısı ise 0.81 'dir.

\section{Verilerin Analizi}

Öğretmenlerin eğitim inançlarını ve meslekî değerlerini belirlemek amacıyla betimsel istatistikler kullanılmıştır. Öğretmenlerin eğitim inançlarının ve meslekî değerlerinin çeşitli değişkenlere göre karŞılaştırılması için EİÖ’nün alt ölçeklerine ve ÖMDÖ’ye verdikleri cevapların her bir değişkene ilişkin ortalama ve standart sapmaları hesaplanmış, normallik ve varyansların homojenliği kontrol edilmiştir. $\mathrm{Bu}$ incelemelere göre; "branş, öğrenim durumu ve görev yaptığı okulun sosyo-ekonomik seviyesi” değişkenleri için tek yönlü varyans analizi (ANOVA) ve normal olmayan dağılımların karşılaştırılmasında 
Kruskal Wallis H Testi kullanılmıştır. Öğretmenlerin EİÖ ile ÖMDÖ’ye verdikleri yanıtlardan elde edilen puanlar arasındaki ilişkiler Pearson Momentler Çarpımı Korelasyon Katsayısı (r) ile incelenmiştir. Analiz sonucu elde edilen korelasyon katsayısı, mutlak değer olarak, 0.70-1.00 arası yüksek; 0.69-0.30 arası orta; 0.29-0.00 arası ise düşük seviyede ilişki olarak yorumlanmıştır (Büyüköztürk, 2005).

\section{Bulgular}

Bu bölümde, araştırmanın amaçları doğrultusunda; ilk önce, öğretmenlerin eğitim inançlarını ve meslekî değerleri benimseme seviyeleri belirlenmiş ve çeşitli değişkenlere göre karşılaştırılmış, daha sonra ise bu iki değişken arasındaki ilişki incelenmiştir.

\section{Öğretmenlerin Eğitim İnançları ve Meslekî Değerlere Sahip Olma}

\section{Seviyelerine İlişkin Bulgular}

Öğretmenlerin eğitim inançlarına ve meslekî değerlerine ilişkin betimsel istatistikler Tablo 1'de sunulmuştur.

Tablo 1. Öğretmenlerin Eğitim İnançlarına ve Meslekî Değerlerine İlişkin Betimsel İstatistikler

\begin{tabular}{clccccc}
\hline \multirow{2}{*}{ Değişken } & $\mathbf{N}$ & $\mathbf{K}$ & $\bar{x}$ & $\mathbf{S}$ & $\bar{x} / \mathbf{K}$ \\
& İlerlemecilik & 253 & 13 & 54.33 & 6.31 & 4.18 \\
\multirow{2}{*}{ Eğitim } & Varoluşçu Eğitim & 253 & 7 & 30.49 & 3.66 & 4.36 \\
İnanc1 & Yeniden Kurmacılık & 253 & 7 & 27.78 & 3.81 & 3.97 \\
& Dâimîcilik & 253 & 8 & 31.99 & 4.02 & 3.99 \\
& Esâsîcilik & 253 & 5 & 14.04 & 3.79 & 2.81 \\
\hline \multirow{3}{*}{ Meslekî } & Farklıliklara Saygı Duyma & 253 & 8 & 33.63 & 4.02 & 4.20 \\
Değer & Kişisel ve Toplumsal Sorumluluk & 253 & 8 & 27.96 & 4.98 & 3.50 \\
& Şiddete Karşı Olma & 253 & 5 & 15.72 & 3.50 & 3.14 \\
& İşirliğine Açık Olma & 253 & 3 & 11.58 & 2.13 & 3.86 \\
& Toplam & 253 & 24 & 89.47 & 9.40 & 3.73 \\
\hline
\end{tabular}


Tablo 1'de de görüldüğü gibi, öğretmenlerin en yüksek katılım gösterdikleri eğitim inancı boyutları sırasıyla; "Varoluşçu Eğitim" ( $\bar{x}=4.36, \mathrm{~s}=.52)$, "İlerlemecilik" ( $\bar{x}=4.18, \mathrm{~s}=.49)$, "Dâimîcilik" ( $\bar{x}=3.99, \mathrm{~s}=.50)$, "Yeniden Kurmac1l1k" $(\bar{x}=3.97, \mathrm{~s}=.54)$ ve "Esâsîcilik”tir $(\bar{x}=2.81, \mathrm{~s}=.76)$. Öğretmenlerin meslekî değerleri benimseme seviyelerinin ise orta seviyenin üzerinde olduğu görülmektedir $(\bar{x}=3.73, \mathrm{~s}=.39)$. Bununla birlikte öğretmenlerin en çok "Farklılıklara Saygı Duyma" ( $\bar{x}=4.20, \mathrm{~s}=.50)$ ve "İşbirliğine Açık Olma" $(\bar{x}=3.86$, $\mathrm{s}=.71$ ); en az ise "Şiddete Karşı Olma" değerine sahip oldukları belirlenmiştir $(\bar{x}=3.14, \mathrm{~s}=.70)$.

\section{Öğretmenlerin Eğitim İnançlarının Çeşitli Değişkenlere Göre İn- celenmesine İlişkin Bulgular}

Araştırmanın amaçları doğrultusunda, öğretmenlerin eğitim inançlarının; öğrenim seviyesine, görev yapılan okulun sosyo-ekonomik seviyesine ve branşa göre farklılaşıp farklılaşmadığ incelenmiştir. Öğretmenlerin eğitim inançlarının öğrenim seviyelerine göre karşılaştırılmasına ilişkin analiz sonuçları Tablo 2'de sunulmuştur. Tabloda görüldüğü üzere öğretmenlerin eğitim inançları öğrenim seviyesine göre yalnızca "Dâimîcilik" boyutunda anlamlı olarak farklılaşmaktadır $\left(x^{2}=7.348, p<.05\right)$. Farkın kaynağını belirlemek için yapılan Mann Whitney U Testi sonuçlarına göre, öğretmenlerin "Dâimîcilik" eğitim inançlarında; önlisans seviyesinde öğrenim gören öğretmenlerle lisans $(\mathrm{U}=1399, p<.05)$ ve lisansüstü $(\mathrm{U}=185, p<.05)$ seviyede öğrenim gören öğretmenler arasında, önlisans seviyesinde öğrenim görenler lehine, anlamlı farklar vardır. Öğretmenlerin eğitim 
inançları, "İlerlemecilik", "Varoluşçu Eğitim", "Yeniden Kurmacılık" ve "Esâsîcilik" boyutlarında ise öğrenim seviyesine göre anlamlı olarak farklılaşmamaktadır.

Tablo 2. Eğitim İnançlarının Öğrenim Seviyesine Göre Karşılaştırılmas1

\begin{tabular}{|c|c|c|c|c|c|c|c|}
\hline $\begin{array}{l}\text { Ĕgitim } \\
\text { İnancı }\end{array}$ & $\begin{array}{l}\text { Öğrenim } \\
\text { Seviyesi }\end{array}$ & $\mathbf{N}$ & $\begin{array}{l}\text { Sura } \\
\text { ort. }\end{array}$ & sd & $x^{2}$ & $p$ & $\begin{array}{c}\text { Anlamlı } \\
\text { fark }\end{array}$ \\
\hline \multirow{3}{*}{ İlerlemecilik } & Önlisans & 20 & 149.9 & 2 & \multirow{3}{*}{2.15} & \multirow{3}{*}{.34} & \\
\hline & Lisans & 199 & 124.81 & 2 & & & \\
\hline & Lisansüstü & 34 & 126.37 & 2 & & & \\
\hline \multirow{3}{*}{$\begin{array}{l}\text { Varoluşçu } \\
\text { Eğitim }\end{array}$} & Önlisans & 20 & 148.40 & 2 & \multirow{3}{*}{2.19} & \multirow{3}{*}{.33} & \\
\hline & Lisans & 199 & 124.05 & 2 & & & \\
\hline & Lisansüstü & 34 & 131.66 & 2 & & & \\
\hline \multirow{3}{*}{$\begin{array}{l}\text { Yeniden } \\
\text { Kurmacilık }\end{array}$} & Önlisans & 20 & 131.60 & 2 & \multirow{3}{*}{.33} & \multirow{3}{*}{.85} & \\
\hline & Lisans & 199 & 125.64 & 2 & & & \\
\hline & Lisansüstü & 34 & 132.26 & 2 & & & \\
\hline \multirow{3}{*}{ Dâimîcilik } & Önlisans & 20 & 164.30 & 2 & \multirow{3}{*}{7.35} & \multirow{3}{*}{.03} & \\
\hline & Lisans & 199 & 126.35 & 2 & & & $\begin{array}{l}1>2(U=1399) \\
1>3(U-185)\end{array}$ \\
\hline & Lisansüstü & 34 & 108.85 & 2 & & & \\
\hline \multirow{3}{*}{ Esâsîcilik } & Önlisans & 20 & 129.45 & 2 & \multirow{3}{*}{.026} & \multirow{3}{*}{99} & \\
\hline & Lisans & 199 & 126.86 & 2 & & & \\
\hline & Lisansüstü & 34 & 126.37 & 2 & & & \\
\hline
\end{tabular}

$p<0.05$

Öğretmenlerin eğitim inançlarının görev yaptıkları okulun sosyo-ekonomik seviyesine göre karşılaştırılmasına ilişkin analiz sonuçları Tablo 3’te verilmiştir. Tabloda da görüldüğü gibi, öğretmenlerin eğitim inançları görev yaptıkları okulun sosyo-ekonomik seviyesine göre, "Yeniden Kurmac1lık" $\left(x^{2}=6.750, p<.05\right)$ ve "Dâimîcilik" $\left(x^{2}=14.091, p<.05\right)$ boyutlarında anlamlı olarak farklılaşmaktadır. Farkın kaynağını belirlemek için yapılan Mann Whitney U Testi sonuçlarına göre, öğretmenlerin "Yeniden Kurmacılık" ( $U=1406, p<.05)$ ve "Dâimîcilik" ( $\mathrm{U}=1222, p<.01)$ eğitim inançlarında, orta ve üst sos- 
yo-ekonomik seviyede görev yapan öğretmenler arasında, üst sosyo-ekonomik seviye lehine, anlamlı fark bulunmuştur. Öğretmenlerin "Yeniden Kurmacilık" (U=548, p<.05) ve "Dâimîcilik" (U=369, $p<.01)$ boyutlarındaki eğitim inançlarında, alt ve üst sosyo-ekonomik seviyede görev yapanlar arasında, üst sosyo-ekonomik seviye lehine anlamlı farklar bulunmuştur. Analiz sonuçları, öğretmenlerin, "İlerlemecilik" ( $\left.x^{2}=3.99, p>.05\right)$, "Varoluşçu Eğitim" $\left(x^{2}=1.570, p>.05\right)$ ve "Esâsîcilik" ( $\left.x^{2}=.987, p>.05\right)$ boyutlarındaki eğitim inançlarının, görev yaptıkları okulun sosyo-ekonomik seviyesine göre anlamlı bir farklılık göstermediğini ortaya koymaktadır.

Tablo 3. Eğitim İnançlarının Görev Yapılan Okulun Sosyo-Ekonomik Seviyesine Göre Karşılaştırılması

\begin{tabular}{|c|c|c|c|c|c|c|c|}
\hline Eğitim İnancı & $\begin{array}{c}\text { Okulun } \\
\text { sosyo- } \\
\text { ekonomik } \\
\text { seviyesi }\end{array}$ & $\mathbf{N}$ & $\begin{array}{l}\text { Sira } \\
\text { ort. }\end{array}$ & sd & $x^{2}$ & $p$ & Anlamlı fark \\
\hline \multirow{3}{*}{ İlerlemecilik } & Alt SES & 61 & 123.02 & 2 & \multirow{3}{*}{4.00} & \multirow{3}{*}{.14} & \\
\hline & Orta SES & 167 & 124.31 & 2 & & & \\
\hline & Üst SES & 25 & 154.70 & 2 & & & \\
\hline \multirow{3}{*}{$\begin{array}{l}\text { Varoluşçu } \\
\text { Eğitim }\end{array}$} & Alt SES & 61 & 130.18 & 2 & \multirow{3}{*}{1.57} & \multirow{3}{*}{.46} & \\
\hline & Orta SES & 167 & 123.57 & 2 & & & \\
\hline & Üst SES & 25 & 142.16 & 2 & & & \\
\hline \multirow{3}{*}{$\begin{array}{l}\text { Yeniden } \\
\text { Kurmacilık }\end{array}$} & Alt SES & 61 & 125.11 & 2 & \multirow{3}{*}{6.75} & \multirow{3}{*}{.03} & $1<3,(\mathrm{U}=548)$ \\
\hline & Orta SES & 167 & 122.32 & 2 & & & $2<3,(\mathrm{U}=1406)$ \\
\hline & Üst SES & 25 & 162.84 & 2 & & & \\
\hline \multirow{3}{*}{ Dâimîcilik } & Alt SES & 61 & 114.02 & 2 & \multirow{3}{*}{$\begin{array}{c}14.0 \\
9\end{array}$} & \multirow{3}{*}{.00} & $1<3(\mathrm{U}=369)$ \\
\hline & Orta SES & 167 & 124.20 & 2 & & & $2<3(\mathrm{U}=1222)$ \\
\hline & Üst SES & 25 & 177.36 & 2 & & & \\
\hline \multirow{3}{*}{ Esâsîcilik } & Alt SES & 61 & 123.27 & 2 & \multirow{3}{*}{1.49} & \multirow{3}{*}{.99} & \\
\hline & Orta SES & 167 & 125.88 & 2 & & & \\
\hline & Üst SES & 25 & 143.56 & 2 & & & \\
\hline
\end{tabular}

$p<0.05$ 
Öğretmenlerin eğitim inançları branşa göre karşılaştırıldığında ise EİÖ’nün "İlerlemecilik" [F(4-248)=.195, p>0.05], "Varoloşcu Eğitim" $\quad[\mathrm{F}(4-248)=.439, \quad p>0.05], \quad$ "Yeniden Kurmacilık" $[\mathrm{F}(4-248)=.583, p>0.05]$, "Dâimîcilik" $[\mathrm{F}(4-248)=.773, p>0.05]$ ve "Esâsîcilik" [F(4-248)=.742, $p>0.05]$ boyutlarından alınan puan branşa göre anlamlı olarak farklılaşmamaktadır.

\section{Öğretmenlerin Meslekî Değer Seviyelerinin Çeşitli Değişkenlere Göre İncelenmesine İlişkin Bulgular}

Araştırmanın amaçları doğrultusunda, öğretmenlerin meslekî değer seviyelerinin; öğrenim seviyesine, görev yapılan okulun sosyo-ekonomik seviyesine ve branşa göre farklılaşıp farklılaşmadığ 1 incelenmiştir.

Öğretmenlerin meslekî değer seviyeleri öğrenim seviyelerine göre karşılaştırıldığında, "Farklılıklara Sayg1 Duyma" $\left(x^{2}=1.265\right.$, $p>.05)$, "Kişisel ve Toplumsal Sorumluluk" $\left(x^{2}=1.858, p>.05\right)$, "Şiddete Karşı Olma" ( $\left.x^{2}=.219, p>.05\right)$, "İşbirliğine Açık Olma” $\left(x^{2}=1.527\right.$, $p>.05)$ boyutlarında ve toplam puanda $\left(x^{2}=1.324, p>.05\right)$ anlamlı bir fark bulunmamıştır.

Öğretmenlerin meslekî değerleri, görev yaptıkları okulun sosyo-ekonomik seviyesine göre karşılaştırıldığında, yalnızca "Farklılıklara Sayg1 Duyma" $\left(x^{2}=5.981, p<.05\right)$ boyutunda, üst ve orta sosyo-ekonomik seviyedeki okullarda görev yapan öğretmenler arasında, üst sosyo-ekonomik seviyedeki okullarda görev yapan öğretmenler lehine, anlamlı fark bulunmuştur ( $\mathrm{U}=1494, p<.05)$. Aynı boyutta, alt 
sosyo-ekonomik seviyede görev yapan öğretmenler ile orta ( $U=4598$, $p>.05)$ ve üst ( $\mathrm{U}=599, p>.05)$ sosyo-ekonomik seviyede görev yapan öğretmenler arasında ise anlamlı fark yoktur. Öğretmenlerin ÖMDÖ’nün "Kişisel ve Toplumsal Sorumluluk" $\left(x^{2}=2.078 p\right.$ >.05), "Şiddete Karşı Olma” $\left(x^{2}=.588, p>.05\right)$, "İşbirliğine Açık Olma” $\left(x^{2}=4.636\right.$, $p>.05)$ boyutlarından aldıkları puanların ve ölçekten aldıkları toplam puanın $\left(x^{2}=1.324, p>.05\right)$ ise görev yaptıkları okulun sosyo-ekonomik seviyesine göre anlamlı biçimde farklılaşmadığı belirlenmiştir.

Tablo 4. Meslekî Değerlerin Branşlara Göre Karşılaştırılması

\begin{tabular}{|c|c|c|c|c|c|c|c|c|}
\hline $\begin{array}{c}\text { Meslekî } \\
\text { Değer }\end{array}$ & Branş & $\mathbf{N}$ & $\bar{x}$ & $\mathbf{S}$ & sd & $\mathbf{F}$ & $p$ & $\begin{array}{c}\text { Fark } \\
\text { (LSD) }\end{array}$ \\
\hline & 1. Fen Bilgisi & 31 & 4.17 & .41 & \multirow{5}{*}{$4-248$} & \multirow{5}{*}{1.30} & \multirow{5}{*}{.26} & \\
\hline Farklılık- & 2. Matematik & 47 & 4.07 & .56 & & & & \\
\hline lara Sayg1 & 3. Sinıf Öğr. & 84 & 4.27 & .51 & & & & \\
\hline \multirow[t]{2}{*}{ Duyma } & 4.Sosyal Bil. & 45 & 4.19 & .50 & & & & \\
\hline & 5.Türkçe & 46 & 4.25 & .49 & & & & \\
\hline \multirow{5}{*}{$\begin{array}{l}\text { Kişisel } \\
\text { Toplumsal } \\
\text { Sorumlu- } \\
\text { luk }\end{array}$} & 1. Fen Bilgisi & 31 & 3.51 & .65 & \multirow{5}{*}{$4-248$} & \multirow{5}{*}{2.67} & \multirow{5}{*}{.03} & \multirow{5}{*}{$\begin{array}{l}2<3,2<5 \\
4<3,4<5\end{array}$} \\
\hline & 2. Matematik & 47 & 3.33 & .62 & & & & \\
\hline & 3. Sinıf Öğr. & 84 & 3.60 & .59 & & & & \\
\hline & 4. Sosyal Bil. & 45 & 3.34 & .61 & & & & \\
\hline & 5. Türkçe & 46 & 3.61 & .63 & & & & \\
\hline \multirow{5}{*}{$\begin{array}{l}\text { Şiddete } \\
\text { Karşı } \\
\text { Olma }\end{array}$} & 1. Fen Bilgisi & 31 & 2.88 & 72 & \multirow{5}{*}{$4-248$} & \multirow{5}{*}{1.51} & \multirow{5}{*}{.20} & \\
\hline & 2. Matematik & 47 & 3.11 & .70 & & & & \\
\hline & 3. Sınıf Öğr. & 84 & 3.18 & .67 & & & & \\
\hline & 4. Sosyal Bil. & 45 & 3.21 & .70 & & & & \\
\hline & 5. Türkçe & 46 & 3.23 & .72 & & & & \\
\hline \multirow{5}{*}{$\begin{array}{l}\text { İşbirliğine } \\
\text { Açık Olma }\end{array}$} & 1. Fen Bilgisi & 31 & 3.67 & .55 & \multirow{5}{*}{$4-248$} & \multirow{5}{*}{7.44} & \multirow{5}{*}{.00} & \multirow{5}{*}{$\begin{array}{l}1<3, \\
2<3,4<3 \\
1<5, \\
2<5,4<5\end{array}$} \\
\hline & 2. Matematik & 47 & 3.67 & .63 & & & & \\
\hline & 3. Sınıf Öğr. & 84 & 4.09 & .72 & & & & \\
\hline & 4. Sosyal Bil. & 45 & 3.55 & .70 & & & & \\
\hline & 5. Türkçe & 46 & 4.08 & .71 & & & & \\
\hline \multirow{5}{*}{ Toplam } & 1. Fen Bilgisi & 31 & 3.66 & .27 & \multirow{5}{*}{$4-248$} & \multirow{5}{*}{2.65} & \multirow{5}{*}{.03} & \multirow{5}{*}{$2<3,2<5$} \\
\hline & 2. Matematik & 47 & 3.62 & .41 & & & & \\
\hline & 3. Sinıf Öğr. & 84 & 3.80 & .38 & & & & \\
\hline & 4. Sosyal Bil. & 45 & 3.67 & .39 & & & & \\
\hline & 5. Türkçe & 46 & 3.80 & .42 & & & & \\
\hline
\end{tabular}

$p<.05$ 
Öğretmenlerin meslekî değerlerinin branşlarına göre karşılaştırılması sonucu elde edilen bulgular Tablo 4'te verilmiştir. Öğretmenlerin meslekî değerleri branşa göre karşılaştırıldığında; "Kişisel ve Toplumsal Sorumluluk" [F(4-248)=2.67, p<0.05] ve "İşbirliğine Açık Olma” $[\mathrm{F}(4-248)=7.44, p<0.01]$ boyutlarında ve toplam puanda $[\mathrm{F}(4-$ 248)=2.65, $p<0.05]$ anlamlı farklar bulunmuştur. "Kişisel ve Toplumsal Sorumluluk" boyutunda, sınıf öğretmenlerinin meslekî değer seviyesi, matematik ve sosyal bilgiler öğretmenlerinden; Türkçe öğretmenlerinin meslekî değer seviyesi de matematik ve sosyal bilgiler öğretmenlerinden daha yüksektir. "İşbirliğine Açık Olma” boyutunda, sınıf öğretmenlerinin meslekî değerleri fen bilgisi, matematik ve sosyal bilgiler öğretmenlerinden; Türkçe öğretmenlerinin meslekî değer seviyeleri de fen bilgisi, matematik ve sosyal bilgiler öğretmenlerinden daha yüksektir. ÖMDÖ'den alınan toplam puanda ise sınıf öğretmenlerinin ve Türkçe öğretmenlerinin meslekî değer seviyeleri matematik öğretmenlerinden daha yüksektir. Öğretmenlerin meslekî değerlerinin, branşa göre, "Farklılıklara Saygı Duyma" $[\mathrm{F}(4-248)=1.30, p>0.01]$ ve "Şiddete Karşı Olma" [F(4-248)=1.51, $p>0.01]$ boyutlarında ise anlamlı olarak farklılaşmadığı belirlenmiştir.

\section{Öğretmenlerin Eğitim İnançları ile Meslekî Değerleri Arasındaki İlişkiye İlişkin Bulgular}

Araştırmanın son amacı doğrultusunda, öğretmenlerin eğitim inançları ile meslekî değerleri arasındaki ilişki incelenmiş ve analiz sonuçları Tablo 5'te sunulmuştur. 
Tablo 5. Öğretmenlerin Eğitim İnançları ile Meslekî Değerleri Arasındaki İlişki

\begin{tabular}{|c|c|c|c|c|c|c|}
\hline \multirow{2}{*}{\multicolumn{2}{|c|}{$\begin{array}{c}\text { Ölçekler } \\
\text { Alt } \\
\text { Boyutlar }\end{array}$}} & \multicolumn{5}{|c|}{ EIIÖ } \\
\hline & & İlerlemecilik & $\begin{array}{l}\text { Varoluşçu } \\
\text { Eğitim }\end{array}$ & $\begin{array}{l}\text { Yeniden } \\
\text { Kurmacilik }\end{array}$ & Dâimîcilik & Esâsîcilik \\
\hline \multirow{5}{*}{ 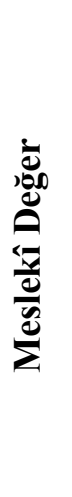 } & $\begin{array}{l}\text { Farkll11klara } \\
\text { Sayg1 } \\
\text { Duyma }\end{array}$ & $.47 * *$ & $.54 * *$ & $.41^{* *}$ & $.35^{* *}$ & $-.17 * *$ \\
\hline & $\begin{array}{l}\text { Kişisel ve } \\
\text { Toplumsal } \\
\text { Sorumluluk }\end{array}$ & $.23 * *$ & $.14^{*}$ & $.33^{* *}$ & $.22 * *$ & $-.10^{*}$ \\
\hline & $\begin{array}{l}\text { Şiddete } \\
\text { Karşı Olma }\end{array}$ & $.19^{* *}$ & $.25^{* *}$ & .10 & $.11 *$ & $-.45 * *$ \\
\hline & $\begin{array}{l}\text { İșbirliugine } \\
\text { Açı Olma }\end{array}$ & $.36^{* *}$ & $.30^{* *}$ & $.32^{* *}$ & $.18^{* *}$ & $-.15^{*}$ \\
\hline & Toplam & $.51 * *$ & $.50 * *$ & $.50 * *$ & $.41 * *$ & $-.27 * *$ \\
\hline
\end{tabular}

Tablo 5'te görüldüğü gibi, öğretmenlerin eğitim inançları ile meslekî değerleri arasında anlamlı düzeyde ilişkiler bulunmaktadır. Öğretmenlerin eğitim inançları ile meslekî değerleri arasındaki ilişki $\mathrm{r}=0.11$ ile $\mathrm{r}=0.54$ arasında değiş̧mektedir. Analiz sonuçlarına göre, iki değişken arasındaki en yüksek ilişki "Varoluşçu Eğitim" ile "Farklıl1klara Saygı Duyma" alt boyutları arasındadır $(\mathrm{r}=.54, p<.01)$. Bu ilişki pozitif ve orta seviyededir. En düşük ilişki ise "Dâimîcilik" ile "Şiddete Karşı Olma" ( $\mathrm{r}=.11, p<0.05)$ boyutları arasındadır. Bu ilişkinin ise pozitif yönde ve düşük seviyede olduğu görülmektedir. Ayrıca "Esâsîcilik" eğitim inancı ile "Farkll1ıklara Saygı Duyma" (r=-.171, $p<0.01)$, "Kişisel ve Toplumsal Sorumluluk" ( $\mathrm{r}=-.10, p<0.005)$, "Şiddete Karşı Olma" ( $\mathrm{r}=-.453, p<0.01)$, "İşbirliğine Açık Olma" $(\mathrm{r}=-.154, p<0.05)$ boyutlarına ait puanlar ve ÖMDÖ'den alınan toplam 
puan $(\mathrm{r}=-.266, p<0.01)$ arasında orta ve düşük seviyede, ters yönde anlamlı ilişkiler bulunmuştur.

\section{Sonuç, Tartışma ve Öneriler}

$\mathrm{Bu}$ araştırmada, öğretmenlerin, eğitim inançlarını ve meslekî değerleri benimseme seviyelerinin; eğitim inançlarının ve meslekî değerlerinin bazı değişkenlere göre farklılaşıp farklılaşmadığının, eğitim inançları ile meslekî değerleri arasında anlamlı bir ilişki olup olmadığının belirlenmesi amaçlanmıştır.

Araştırmada ilk olarak, öğretmenlerin eğitim inançları ve meslekî değerleri incelenmiştir. Eğitim inançları açısından öğretmenlerin en yüksek katılım gösterdiği boyutlar, sırayla, "Varoluşçuluk", "İlerlemecilik", "Dâimîcilik", "Yeniden Kurmacilık" ve "Esâsîcilik" alt boyutlarıdır. Bu sonuç doğrultusunda öğretmenlerin çağdaş eğitim felsefelerini benimsedikleri söylenebilir. İlkokul ve ortaokul programlarının "İlerlemecilik" felsefesine dayandığı dikkate alınırsa programın uygulayıcıları olan öğretmenlerin çağdaş eğitim felsefelerini benimsemiş olmaları beklenen bir durumdur. Ayrıca alan-yazında bazı araştırmac1lar, öğretmenlerin her ne kadar hizmet öncesi eğitimlerinde felsefî bir akıma dayalı olarak eğitilmeseler de aldıkları eğitim sonucunda bazı görüş ve inanışlar geliştirdiklerini iddia etmektedirler (Austin ve Reinhardt, 1999; Kagan, 1992; Pajares, 1992). Bu bağlamda araştırma sonucu, hizmet öncesi öğretmen eğitiminin, öğretmenlerin çağdaş eğitim felsefelerini benimsemelerine katkısının olduğunu göstermektedir. Alan-yazında öğretmenlerin/öğretmen adaylarının benimsedikleri eğitim inançlarıyla ilgili yapılan pek çok çalışma, bu çalışmanın sonuçla- 
rıyla benzerlik göstermektedir (Alkın-Şahin, Tunca ve Ulubey, 2013; Çalışkan, 2013; Çoban, 2007; Doğanay ve Sarı, 2003; Doğanay, 2011; Duman ve Ulubey, 2008; Ekiz, 2005; Erbaş, 2013; Ilgaz, Bülbül ve Çuhadar, 2013; Kanatlı ve Schreglman, 2014; Karadağ, Baloğlu ve Kaya, 2009; Livingston, McClain ve DeSpain, 1995; Tekin ve Üstün, 2008; Tunca, Alkın-Şahin ve Oğuz, 2014; Türkeli, 2011; Yapıc1, 2013). Araştırmada en yüksek seviyede benimsenen eğitim felsefesinin "Varoluşçuluk" olması, alan-yazındaki bazı araştırmaların sonuçları ile örtüşürken (Alkın-Şahin, Tunca ve Ulubey, 2013; Alkın-Şahin ve Oğuz, 2014; Altınkurt, Yılmaz ve Oğuz, 2012; Ilgaz, Bülbül ve Çuhadar, 2013; Yılmaz ve Tosun, 2013; Tunca,), bazılarıyla örtüşmemektedir (Çetin, İlhan ve Arslan, 2012; Doğanay ve Sarı, 2003; Duman, 2008; Tekin ve Üstün, 2008). Bu araştırmalar kendi içinde incelendiğinde, çalışmanın sonucunu destekleyen araştırmalarda veri toplama aracı olarak "Eğitim İnançları Ölçeği”"nin (Yılmaz, Altınkurt ve Çokluk, 2011) kullanıldı̆̆g, desteklemeyen araştırmalarda ise "Felsefî Tercih Değerlendirme Ölçeği”nin (Doğanay ve Sarı, 2003) kullanıldığı dikkat çekmektedir. Bu durum, Alkın-Şahin, Tunca ve Ulubey'in (2013) çalışmalarında vurguladıkları üzere, bir kez daha, araştırmalarda varoluşçuluğa ilişkin sonuçların farklılığının, kullanılan ölçme araçlarından kaynaklandığını doğrulamaktadır. Araştırmada öğretmenlerin meslekî değerler açısından ise kendilerini yeterli gördükleri sonucuna ulaşılmıştır. Meslekî değerler açısından, öğretmenlerin kendilerini görece en yetersiz gördükleri alt boyut "Şiddete Karşı Olma”dır. Türkiye'de 2005 yılında, ilköğretim programlarının yeniden düzenlenmesi ile programın dayandığı felsefe değişmiş, buna bağlı olarak, öğretmen 
ve öğrenci rollerine ilişkin anlayışlar farklılaşmıştır. Öğrenci merkeze alınarak onun ilgi, gereksinim ve tutumları ön plâna çıkarılmıştır. Ayrıca öğrencilerin güven ortamı içinde eğitim kurumlarına devam edebilmelerini sağlamak ve eğitim sisteminden istenilen başarıyı elde edebilmek için Millî Eğitim Bakanlığı tarafindan 14.03.2006 Tarih ve 3164 Sayılı Genelge yayımlanmış ve genelgede "Okullar, öğretmen-öğrenci, öğrenci-öğrenci, okul-aile, aile-öğrenci arasında şiddet, zorbalık ve saldırganlık içeren davranışların kabul edilmeyeceğini kesin ve temel bir anlayış olarak benimseyecek ve bu anlayışın uygulanmasını sağlayacaktır." ifadesine yer verilmiştir (MEB, 2006). Hem programda yapılan düzenlemeler hem de genelgede yapılan açıklamalar dikkate alındığında, öğretmenlerin "Şiddete Karşı Olma" değerine daha yüksek düzeyde sahip olmaları beklenmektedir. Ancak alan-yazında bu konuda yapılan çalışmalar da araştırma sonucunu desteklemektedir (Gözütok, 2008; Hatunoğlu ve Hatunoğlu, 2005; Tunca, 2012). Öğretmenlerin meslekî değerler açısından kendilerini en yeterli gördükleri alt boyut ise "Farklılıklara Sayg1 Duyma"dır. Bu sonuç, ilkokul ve ortaokul öğretmenlerinin meslekî değerlerini aynı ölçeği kullanarak inceleyen Tunca'nın (2012) araştırma sonucuyla benzerlik göstermektedir. Alan-yazında konuyla ilgili yapılan diğer çalışmaların sonuçları incelendiğinde de araştırma sonucu ile benzerlik gösteren çalışmaların olduğu görülmektedir. Meselâ, çalışmasında öğretmenlerin demokratik tutumlarını inceleyen Yurtseven (2003), öğretmenlerin “Ayrımcılık, Adalet ve Eşitlik” değerlerine sahip oldukları; Çoban, Karaman ve Doğan (2010) yaptıkları çalışmada öğretmen adaylarının kültürel farklılıklara ilişkin görüşlerinin olumlu 
yönde olduğu; Altınkurt ve Y1lmaz (2011) ise öğretmenlerin en s1k gösterdiği meslekî etik davranışların "Farklılıklara Saygı Duyma/Ayrımcılık Yapmama” değeriyle ilgili olduğu sonucuna ulaşmıştır.

Araştırmada ikinci olarak, öğretmenlerin eğitim inançları ve meslekî değerleri çeşitli değişkenlere göre incelenmiştir. Öğretmenlerin eğitim inançları öğrenim seviyesine göre incelendiğinde, önlisans mezunu öğretmenlerin lisans ve yüksek lisans mezunu öğretmenlere göre "Dâimîcilik" eğitim felsefesini daha yüksek seviyede benimsedikleri sonucuna ulaşılmıştır. Cumhuriyetin kuruluşundan bu yana Türk eğitim sistemi, her ne kadar kâğıt üzerinde pragmatist felsefeye ve onun eğitimde bir uzantısı olan "İlerlemecilik"eğitim felsefesine dayalı olsa da, "İlerlemeciliğin" değil, "Dâimîciliğin" ve "Esâsîciliğin" etkisinde kalınmıştır. Buna göre öğrenci yerine öğretmen ve konular merkeze alınmış; bilimsel yöntemi kullanan, özgür ve esnek düşünen bireyler yerine, öğretmenin söylediklerini, kitapların yazdıklarını ezberleyen; bildiklerinin kesin doğru olduğunu savunan bireyler yetiştirilmiştir (Sönmez, 2005). Bu bağlamda önlisans mezunu öğretmenlerin "Dâimîcilik" felsefesini benimsemeleri, aldıkları eğitimin yapısı ve özellikleri, 2005 yılında yapılan programlardaki düzenlemelere kadar verdikleri eğitim, eğitim inancının doğası gereği istikrarlı ve değişime dirençli yapısı (Kagan, 1992; Pajares, 1992) dikkate alındığında, beklenen bir durum olarak görülebilir. Araştırmada, öğretmenlerin meslekî değerlerinin ise öğrenim seviyesine göre farklılaşmadığı sonucuna ulaşılmıştır. Bu sonuç öğretmenlerin eğitim seviyesi arttıkça, aldıkları eğitime bağlı olarak meslekî değerleri benimseme seviyelerinin de 
artması yönündeki beklenti ile çelişmektedir. Ne yazık ki, Tunca da (2012) ilkokul ve ortaokul öğretmenlerinin meslekî değerlerini incelediği çalışmada aynı sonuca ulaşmıştır.

Araştırmada incelenen bir diğer değişken, öğretmenlerin görev yaptıkları okulların sosyo-ekonomik seviyeleridir. Öğretmenlerin eğitim inançları, görev yaptıkları okulun sosyo-ekonomik seviyesine göre incelendiğinde, üst sosyo-ekonomik seviyeye sahip okullarda görev yapan öğretmenlerin, alt ve orta sosyo-ekonomik seviyeye sahip okullarda görev yapan öğretmenlere göre "Yeniden Kurmacilık" ve "Dâimîcilik" eğitim felsefelerini daha fazla benimsedikleri sonucuna ulaşılmıştır. Bilindiği gibi, üst sosyo-ekonomik seviyedeki okullar gerek fiziksel alt yapı gerekse sosyo-kültürel koşullar açısından öğrencilere çok daha iyi ortamlar sunabilme olanağına sahiplerdir. $\mathrm{Bu}$ durum, üst sosyo-ekonomik seviyedeki okullarda görev yapan öğretmenlerin, "eğitimin amacının toplumu yeniden yapılandırmak ve geliştirmek olduğu ve okulların toplumsal değişimi sağlamada önemli bir araç olduğu” görüşünü savunan yeniden kurmacılık eğitim felsefesini daha fazla benimsemelerine etki etmiş olabilir. Öğretmenler tarafından "Dâimîcilik" eğitim felsefesinin benimsenmesinin nedeni ise ülkede konuyu merkeze alan, ezbere dayalı, alt bilişsel davranışları ölçen, rekabete odaklanan bir sınav sisteminin olmasıyla açıklanabilir. Gerek öğrencilerin gerekse okulların başarılarının söz konusu sınav sisteminden alınan sonuçlara göre değerlendirilmesi öğretmenleri "Dâimîcilik" eğitim felsefesini benimsemeye itiyor olabilir. Öğretmenlerin meslekî değerleri görev yaptıkları okulun sosyo-ekonomik 
seviyesine göre incelendiğinde, üst sosyo-ekonomik seviyeye sahip okullarda görev yapan öğretmenlerin, orta sosyo-ekonomik seviyeye sahip okullarda görev yapan öğretmenlerden "Farklılıklara Sahip Olma" değerini daha çok benimsedikleri sonucuna ulaşılmıştır.

Araştırmada incelenen bir diğer değişken ise öğretmenlerin branşlarıdır. Öğretmenlerin eğitim inançlarının branşlarına göre farklılaşmadığ1 sonucuna ulaşılmıştır. Bu sonuç, öğretmenlerin uyguladıkları programların dayandığı eğitim felsefelerinin aynı olmasından kaynaklanıyor olabilir. Alan-yazında araştırmanın sonuçlarıyla paralellik gösteren çalışmalara rastlanmıştır. Meselâ, Doğanay ve Sarı (2003), Kanatlı ve Schreglman (2014) ve Okut (2009) ilkokul ve ortaokul öğretmenlerinin sahip oldukları eğitim felsefelerini belirlemeye yönelik yaptıkları çalışmalarında, sınıf ve branş öğretmenlerinin benimsedikleri eğitim felsefeleri arasında anlamlı bir farklılık bulunmadığı sonucuna ulaşmışlardır. Benzer bir biçimde, Karadağ, Baloğlu ve Kaya (2009), okul yöneticilerinin eğitim felsefesi akımlarını benimseme durumlarını inceledikleri çalışmalarında, yöneticilerin, eğitim felsefesini benimseme durumlarının branş değişkenine göre farklılık göstermediği sonucuna ulaşmışlardır. Öğretmenlerin meslekî değerleri branşa göre karşılaştırıldığında, "Kişisel ve Toplumsal Sorumluluk" değerini, Türkçe ve sınıf öğretmenlerinin, matematik ve sosyal bilgiler öğretmenlerinden daha çok benimsedikleri sonucuna ulaşılmıştır. Senemoğlu'na göre (2014) bir çocuğun gözünden sınıf öğretmeni, ebeveynlerinden bile önde gelen "yüceltilmiş" bir kişidir. "O" ne derse doğrudur, ne yaparsa iyidir, güzeldir. Çocuğun gözünde böylesine 
yüceleşen sınıf öğretmeni, çocuğun en çok model aldığ 1 kişilerden biridir. Toplumdaki iyi vatandaşın, nitelikli ana-babanın, nitelikli meslek adamının, nitelikli politikacının temelleri sınıf öğretmenleri tarafından oluşturulmaktadır (Senemoğlu, 2014). Sınıf öğretmenlerinin bu çerçevede üstlendikleri rol ve sorumluluklar, onların "Kişisel ve Toplumsal Sorumluluk" değerini daha fazla benimsemelerini, bu değere ilişkin farkındalıklarının daha yüksek olmasını beraberinde getiriyor olabilir. Ayrıca sosyal bilgiler öğretmenlerinin sınıf ve Türkçe öğretmenlerine göre ilgili değeri daha az benimsemeleri beklenti ile çelişmektedir. Çünkü sosyal bilgiler dersi, toplumsal yapı içerisinde bireysel, toplumsal ve kültürel kimliğinin bilincinde olan; demokratik değerleri ve hayat biçimini benimsemiş; ülkesini ve bütün dünyayı ilgilendiren sorunlara duyarlı; problem çözebilen, karar verebilen ve vatandaşlık sorumluluğunun gerektirdiği katılım becerilerini kazanmış bireyler yetiştirilmesini amaçlamaktadır (Yaşar, 2008). Bu bağlamda bu dersin yürütücüsü olan öğretmenlerin öncelikle bu değeri benimsemeleri beklenmektedir. Araştırmanın önemli bir sonucu da sınıf öğretmenlerinin matematik öğretmenlerine göre meslekî değerleri daha fazla benimsemeleridir. İlgili sonuç, Tunca (2012) tarafindan yapılan araştırma sonucuyla örtüşmektedir.

Araştırmada son olarak öğretmenlerin eğitim inançları ile meslekî değerleri arasındaki ilişki incelenmiştir. Araştırmada, öğretmenlerin meslekî değerleri ile "İlerlemecilik", "Varoluşçuluk", "Yeniden Kurmacılık" ve "Dâimîcilik" eğitim felsefeleri arasında orta seviyede ve pozitif ilişkiler bulunmuştur. "İlerlemecilik" ve "Yeniden Kurma- 
c1lık" eğitim felsefelerine dayalı oluşturulan eğitim sisteminin "bireyler arası işbirliğini sağlayıp, demokratik ve sosyal hayatı geliştirerek toplumu yeniden düzenlemeyi” (Sönmez, 2005) amaçladığı dikkate al1nırsa; söz konusu değişkenler arasında daha yüksek seviyede bir ilişki olması beklenmektedir. Araştırmada eğitim inançları ölçeği ile öğretmen meslekî değerler ölçeğinin alt boyutları arasındaki ilişkiler incelendiğinde ise en yüksek seviyede ilişkinin, "Varoluşçu Eğitim" ile "Farklılıklara Saygı Duyma” değeri arasında olduğu sonucuna ulaşılmıştır. "Varoluşçu Eğitim”, "her öğrencinin kendi özelliklerini tanımasına; sınıf içi tartışmalarda tarafsız davranılarak ve herhangi bir doğru dayatılmayarak özgürleşmesine” imkân sağlayan bir yapıdadır. Bu bağlamda "Varoluşçuluk" ile "Farklılıklara Saygı Duyma" değeri arasında yüksek bir ilişki çıkması beklenen bir durumdur. Ayrıca araştırmada "Esâsîcilik" ile "Şiddete Karşı Olma" değeri arasında orta seviyede negatif ve anlamlı bir ilişki olduğu sonucuna ulaşılmıştır. “Öğrencilere kendi kendini denetleme becerisinin kazandırılması amacıyla eğitim ortamlarında çekinmeden zor kullanılabileceğini ya da cezaya başvurulabileceğini" savunan "Esâsîcilik" eğitim felsefesi (Sönmez, 2005) ile "Şiddete Karşı Olma" değeri arasında negatif ve orta seviyede bir ilişkinin çıkması beklenen bir durumdur.

Alan-yazında öğretmenlerin meslekî değerlerini inceleyen çalışma sayısı yok denecek kadar azdır. Dolayısıyla, hem öğretmenlerin meslekî değer seviyelerine ilişkin hem de meslekî değerlerinin ilgili değişkenlere göre farklılaşıp farklılaşmadığına ilişkin daha büyük örneklemler üzerinde daha fazla çalışmanın yapılması gerekmektedir. 
Araştırmada eğitim inançları ile meslekî değerler arasında anlamlı ilişkilerin bulunması, eğitim fakültelerinde eğitim felsefelerine ilişkin farkındalık oluşturmanın meslekî değerlerin daha fazla benimsenmesine katkı sağlayacağına ilişkin ipucu sunmaktadır. Bu bağlamda öncelikle, öğretmen eğitimi programlarına, eğitim felsefelerine ilişkin dersler konularak, hizmet içi eğitim programlarında ise eğitim felsefelerine ilişkin konulara yer verilerek öğretmen adaylarına, öğretmenlere farkındalık kazandırılmalıdır. Ayrıca, eğitim inançları ile meslekî değerler arasındaki ilişkiye yönelik daha güçlü vurguların yapılabilmesi için gelecek araştırmalarda daha büyük çalışma grupları üzerinde araştırmalar yapılabilir.

\section{Kaynakça}

Alkın-Şahin, S., Tunca, N. ve Ulubey, Ö. (2013). The relationship between preservice teachers' educational beliefs and critical thinking tendencies, European Conference on Curriculum Studies. Future Directions: Uncertainty and Possibility. University of Minho. 18-19 Ekim 2013, Portugal-Braga.

Altınkurt, Y. ve Yılmaz, K. (2011).Öğretmen adaylarının öğretmenlerin mesleki etik dışı davranışlar ile ilgili görüşleri. Mehmet Akif Ersoy Üniversitesi Ĕ̈itim Fakültesi Dergisi, 11(22), 113-128.

Altınkurt, Y., Yılmaz, K. ve Oğuz, A. (2012). İlköğretim ve ortaöğretim okulu öğretmenlerinin eğitim inançları. On Dokuz Mayıs Üniversitesi Eğitim Fakültesi Dergisi, 31(22), 1-19.

Austin, J. ve Reinhardt, D. (1999). Philosophy and advocacy: An examination of preservice music teachers' beliefs. Journal of Research in Music Education, 47(1), 18-30. 
Büyükdüvenci, S. (1991). Eğitim felsefesine giriş. Ankara: Savaş Yayınlar1.

Büyüköztürk, Ş. (2005). Sosyal bilimler için veri analizi el kitabı. Ankara: Cantekin Matbaası.

Çalışkan, İ. (2013). Fen öğretmen adaylarının eğitim felsefesi yaklaşımları ile planlama süreçleri üzerine bir çalışma. Hacettepe Üniversitesi Eğitim Fakültesi Dergisi, Özel Sayı(1), 68-83.

Çetin, B., İlhan, M. ve Arslan, S. (2012). Öğretmen adaylarının benimsedikleri eğitim felsefelerinin çeşitli değişkenler açısından incelenmesi. The Journal of Academic Social Science Studies JASS, 5(5), 149-170.

Çoban, A. (2007). Sınıf öğretmenlerinin eğitim sürecine ilişkin felsefi tercihlerini değerlendirme. Üniversite ve Toplum, 7(4). 5 Mart 2014, http://www.universite-toplum.org/pdf/pdf_UT_331.pdf.

Çoban, A. E., Karaman, N. G. ve Doğan, T. (2010).Öğretmen Adaylarının kültürel farklılıklara yönelik bakış açılarının çeşitli demografik değişkenlere göre incelenmesi. Abant İzzet Baysal Üniversitesi Dergisi, 10(1), 125-131.

Doğanay, A. ve Sarı, M. (2003). İlköğretim öğretmenlerinin sahip oldukları eğitim felsefelerine ilişkin algılarının değerlendirilmesi. Türk Eğitim Bilimleri Dergisi, 1(3), 321-339.

Doğanay, A. (2011). Hizmet öncesi öğretmen eğitiminin öğretmen adaylarının felsefi bakış açılarına etkisi. Ĕgitim ve Bilim, 36(161), 332-348.

Duman, B. (2008). Öğrencilerin benimsedikleri eğitim felsefeleriyle kullanıldıkları öğrenme strateji ve öğrenme stillerinin karşılaştırılması. Çukurova Üniversitesi Sosyal Bilimler Enstitüsü Dergisi, 
$17(1), 203-224$.

Duman, B. ve Ulubey, Ö. (2008). Öğretmen adaylarının benimsedikleri eğitim felsefelerinin öğretim teknolojilerini ve interneti kullanma düzeylerine etkisi ile ilgili görüşleri. Muğla Üniversitesi Sosyal Bilimler Enstitüsü Dergisi, 20, 95-114.

Ekiz, D. (2005). Sınıf öğretmeni adaylarının eğitim felsefesi akımlarına ilişkin eğilimlerinin karşılaştırılması. Ondokuz Mayıs Üniversitesi Eğitim Fakültesi Dergisi, 19, 1-11.

Erbaş, M. K. (2013). Determination of physical education teachers' educational beliefs. International Journal of Academic Research, 5(5), 386-392.

Erden, M. (1998). Öğretmenlik mesleğine giriş. İstanbul: Alkım Yayınlar1.

Fang, Z. H. (1996). A review of research on teacher beliefs and practices. Educational Research, 38, 47-65.

Gözütok, D. F. (2008). Eğitim ve şiddet. Ankara: Gazi Kitabevi Yayınlar1.

Haney, J. J., Lumpe, A. T. ve Czerniak, C. M. (2003). Constructivist beliefs about The Science Classroom Learning Environment: Perspectives from Teachers, Administrators, Parents, Community Members, and Students. School Science and Mathematics, 103(8), 366-377.

Hatunoglu, Y. ve Hatunoglu, A. (2005). Öğretmenlerin fiziksel cezalandırmaya ilişkin görüssleri. Atatürk Üniversitesi Sosyal Bilimler Dergisi, 6(2), 105-115.

Hermans, R., Tondeur, J., Valcke, M. ve Van Braak, J. (2008). The impact of primary school teachers' educational beliefs on the 
classroom use of computers. Computers \& Education, 51, 1499-1509.

Ilgaz G., Bülbül T. ve Çuhadar, C. (2013). Öğretmen adaylarının eğitim inançları ile öz-yeterlik algıları arasındaki ilişkinin incelenmesi. Abant İzet Baysal Üniversitesi Eğitim Fakültesi Dergisi, 13(1), 50-65.

Kagan, D. M. (1992). Implications of research on teacher belief. Educational Psychologist, 27(1), 65-90.

Kanatlı, F. ve Schreglman, S. (2014). İlköğretim öğretmenlerinin sahip oldukları eğitim felsefelerine ilişkin algılarının değerlendirilmesi. Gümüşhane Üniversitesi Sosyal Bilimler Elektronik Dergisi, 9, 128-138.

Karadağ, E., Baloğlu, N. ve Kaya, S. (2009). Okul yöneticilerinin eğitim felsefesi akımlarını benimseme düzeylerine ilişkin ampirik bir çalışma. Uludă̆ Üniversitesi Felsefe Dergisi, 12, 181-200.

Karakuş, M. (2006). Öğretmen yetiştirmede felsefenin yeri ve önemi. Çukurova Üniversitesi Ĕ̆itim Fakültesi Dergisi, 1(31), 79-85

Karasar, N. (2005). Bilimsel araştırma yöntemi. Ankara: Nobel Yayın Dağıtım.

Livingston, M. J., McClain, B. R., ve DeSpain, B. C. (1995). Assessing the consistency between teachers' philosophies and educational goals. Education, 116(1), 124-129.

MEB, (2006). Okullarda şiddetin önlenmesi [Broşür]. 15 Ekim 2014, ankara.meb.gov.tr/dosyaindir.asp?dosya $=00767$.

Okut, L. (2009). İlköğretim okulu ögrretmenlerinin ĕgitime ilişkin inançlarına göre etkili ögretmen özellik ve davranışlarına sahip olma dereceleri. Yayınlanmamış doktora tezi, Ankara Üniversi- 
tesi Eğitim Bilimleri Enstitüsü.

Pajares, F. M. (1992). Teachers' beliefs and educational research: Cleaning up a messy construct. Review of Educational Research, 62, 307-332.

Senemoğlu, N. (2014). Stnıf ögrretmeni bilgiyi aktaran kişi değil, bilgiye ulaşma yollarını ögreten kişidir. 10 Eylül 2014, yunus.hacettepe.edu.tr/ n.senem/makaleler/sinif_ogr.htmls.

Seshadri, C. (2008). Philosophy of education as a knowledge field. New Delhi: National University of Educational Planning and Administration.

Sönmez, V. (1996). Eğitim felsefesi. Ankara: Anı Yayınc1lık.

Sünbül, A. M. (1996). Öğretmen niteliği ve geliştirilmesi. Ĕ̆itim Yönetimi Dergisi, 4, 597-608.

Tekin, S. ve Üstün, A. (2008). Amasya Eğitim Fakültesi öğretmen adaylarının eğitim süreci hakkındaki felsefi tercihlerinin tespiti. Selçuk Üniversitesi Ahmet Keleşoğlu Eğitim Fakültesi Dergisi, 25, 145-158.

Tunca, N. (2012). İlköğretim öğretmenleri için mesleki değerler ölçeğinin geliştirilmesi ve ilkögretim ögretmenlerinin mesleki değerlerinin belirlenmesi. Yayınlanmamış doktora tezi, Anadolu Üniversitesi Eğitim Bilimleri Enstitüsü.

Tunca, N., Alkın-Şahin, S. ve Oğuz, A. (2014). Öğretmenlerin eğitim inançları ile mesleki değerleri arasındaki ilişki. 1. Avrasya Ĕ̆itim Araştırmaları Kongresi, 24 - 26 Nisan 2014, İstanbul, EJER \& İstanbul Üniversitesi.

Türkeli, A. (2011). Beden eğitimi ögretmenlerinin eğitim felsefeleri ve teknolojiye karşı tutumları. Yayınlanmamış yüksek lisans tezi, 
Gazi Üniversitesi Eğitim Bilimleri Enstitüsü.

Yapıcı, Ş. (2013). Öğretmen ve öğretmen adaylarının eğitim felsefeleri. International Turkish Studies, 8(8), 1431-1452.

Yaşar, Ş. (2008). Sosyal bilgiler ve dünya vatandaşlığı. Ş. Yaşar, (Ed.), Hayat bilgisi ve sosyal bilgiler ögretimi içinde (229-245). Eskişehir: Anadolu Üniversitesi Açıköğretim Yayınları.

Yılmaz, K., Altınkurt, Y. ve Çokluk, Ö. (2011). Eğitim inançları ölçeği'nin geliştirilmesi: Geçerlik ve güvenirlik çalışması. Kuram ve Uygulamada Eğitim Bilimleri, 11(1), 335-350.

Yılmaz, K. ve Tosun, M. F. (2013). Öğretmenlerin eğitim inançları ile öğretmen öğrenci ilişkilerine yönelik görüşleri arasındaki ilişki. Journal of Research in Education and Teaching, 2(4), 205-218.

Yurtseven, R. (2003). Özel ortä̈ğretim kurumlarında çalışan öğretmenlerin demokratik tutumları. Yayımlanmamış yüksek lisans tezi, Çukurova Üniversitesi Eğitim Bilimleri Enstitüsü. 